\title{
Wheel Load Distribution in Four-Sided Concrete Box Culverts
}

\author{
By Elie Awwad \\ Mounir Mabsout ${ }^{\dagger}$ \\ Kassim Tarhinit \\ Hudson Jackson
}

This paper presents the results of a parametric study of wheel load distribution in foursided precast concrete box culverts using three-dimensional finite element analysis $(3 D$ FEA) as compared to the two-dimensional (2D) plane frame analysis. Maximum bending moments and deflections from the 3D-FEA results and the $2 D$ frame analysis were computed and evaluated. Several concrete box culvert sizes were chosen with various span lengths, constant rise, and standard laying width. The culverts were subjected to various combinations of earth loading and AASHTO HS2O wheel loading applied at midspan of the top slab. As the soil cover increases from 0 to $3 \mathrm{~m}$, wheel loads are projected to the top slab using ASTM C890 procedure. The finite element results showed that the effect of wheel loading along mid-span is significant and that the edge loading condition for a single box is more critical than center loading for soil cover less than $0.9 \mathrm{~m}$. The earth loading tends to gradually dominate as the soil cover increases, which is expected based on geotechnical engineering practices. It was shown that the plane frame analysis and 3D-FEA gave similar results for long-span and non-standard box culverts. However, for short-span $(3.6 \mathrm{~m})$ concrete box culverts, the plane frame analysis was less conservative than the 3D-FEA by about $15 \%$ for moments; versus about $5 \%$ for long-span culvert $(7.2 \mathrm{~m})$. The results of this paper will assist bridge engineers in analyzing and designing non-standard precast concrete box culverts and quickly replacing small bridges.

Keywords: Concrete Box Culverts, Earth Pressure, Finite Element Analysis, Wheel Load Distribution.

\section{Introduction}

According to the U.S.A. Federal Highway Administration's 2016 National Bridge Inventory data, $21.7 \%$ of the nation's 603,620 bridges are structurally deficient or functionally obsolete as reported in Better Roads Magazine (November 2016). ${ }^{1}$ Highway Bridges that are either built using cast-in-place concrete or precast concrete panels form about $69 \%$ of all bridges $(423,216)$. Single span reinforced concrete bridges represent about 150,000 and assuming

\footnotetext{
*Associate Professor, Lebanese University, Lebanon.

†Professor, American University of Beirut, Lebanon.

*Professor, U.S. Coast Guard Academy, USA.

'Professor, U.S. Coast Guard Academy, USA.

${ }^{1}$ Better Roads Magazine (2016) Annual Bridge Inventory (Nov).
} 
$22 \%$ of those bridges to be structurally deficient or functionally obsolete. In the 2017 ASCE Infrastructure Report Card, ASCE cited almost $40 \%$ of all bridges are over fifty years or older and an additional $15 \%$ are between the ages of 40 and 49 years. The average bridge age in the U.S.A. was 43 years old while most of the bridges were designed for a lifespan of 50 years. Therefore, an increasing number of bridges will soon need major rehabilitation or replacement. However, this bridge inventory accounts for structures with span lengths greater than $6 \mathrm{~m}(20 \mathrm{ft})$, where the majority of the structurally deficient bridges are short spans, averaging less than $15 \mathrm{~m}(50 \mathrm{ft})$ in length. These deficient bridges are being recommended for weight-limit posting, rehabilitation, or decommissioning and replacement. Thousands of such structures especially with span length are less than $6 \mathrm{~m}(20 \mathrm{ft})$ in every state and municipality may be ignored, not inspected, or not replaced on regular basis due to the lack of funding. This task is left up to each local government to maintain structures spanning less than $6 \mathrm{~m}(20 \mathrm{ft})$ without federal support.

Cast-in-place reinforced concrete box culverts have been designed and used for many years because of special geometry or site conditions. As labor cost continues to rise, increase in traffic volume on highways, and the cost of inconvenience and delays associated with cast-in-place construction methods resulted in the introduction of precast concrete box culverts. To reduce cost and develop alternative to cast-is-place structures, prefabricated reinforced concrete culverts were developed as an economical alternatives for replacing deteriorating short-span bridges and cast-in-place culverts. These prefabricated structures include reinforced concrete arches, three- and four-sided concrete or metal box culverts. The most commonly used type is the precast reinforced concrete culvert due to its durability and minimal field construction time. There are two American Societies for Testing and Materials (ASTM) Specification for Precast Reinforced Concrete Box Culverts design standards: (i) ASTM C1433-16 (AASHTO M273) standard for culverts using AASHTO Standard Specifications, and (ii) ASTM C1577-16 (AASHTO M259) standard for culverts using AASHTO LRFD. Foursided concrete culverts are typically referred to as box-culverts with standard span by rise sizes starting at $0.9 \mathrm{~m} \mathrm{X} 0.6 \mathrm{~m}(3 \mathrm{ft} \times 2 \mathrm{ft})$ and goes up to $3.6 \mathrm{~m} \mathrm{X} 3.6 \mathrm{~m}$ $(12 \mathrm{ft} X 12 \mathrm{ft})$ with one-foot increment. The standard laying length is either $1.8 \mathrm{~m}$ or $2.4 \mathrm{~m}(6 \mathrm{ft}$ or $8 \mathrm{ft})$ depending on the maximum weight limits generate per precast section and transport on the highway to the specific site. The maximum span length of a standard ASTM precast concrete box section is $3.6 \mathrm{~m}$ (12 ft) which may be too small to handle heavy water flow and may require the use of multiple sections placed side-by-side. In this case, the walls of adjacent culverts will act as a pier that may obstruct the flow of water and be associated with flooding problems. Therefore, developing new four-sided box sections with longer spans have proven to be an economical alternative to multiple box-sections.

This paper builds on the study reported by Awwad et al. (2008) by investigating the analysis of longer span $7.2 \mathrm{~m}(24 \mathrm{ft})$ culvert. The finite element analysis (FEA) results of four-sided reinforced concrete box culverts with span

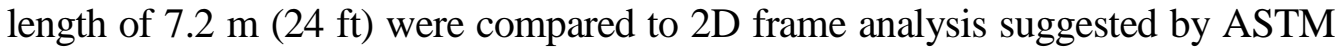
and AASHTO Standard Bridge Specifications (2002). The culvert had constant 
rise and was subjected to various load combinations of earth pressures and AASHTO HS20 wheel loading in the top slab. This study considered the effect of each and/or combinations of soil cover on the culvert behavior, lateral earth pressures applied to side walls, and soil bearing pressure applied to the bottom slab. The results presented in this paper can assist bridge engineers in analyzing and designing precast concrete box culverts with span lengths longer than $3.6 \mathrm{~m}$ (12 ft) subject to various loads or load combinations of dead load, earth pressure, and live load.

\section{Background}

Precast concrete box culverts are typically designed as highway bridges per either AASHTO Standard (2002) or LRFD (2012). These specifications introduced the provision of distributing single or multiple wheel live loads to the bridge superstructure as a function of the depth of soil fill. Therefore, AASHTO suggest the analysis and design of box culverts by reducing the 3D structure to a 2D frame. Abolmaali and Garg (2008) reported the results of a study evaluating the shear behavior and capacity of 42 standard precast concrete box culverts presented in ASTM C1433 subject to AASHTO HS20 truck wheel load. No fill was placed on the top slab of the culverts and rigid bedding material was assumed to support the culverts. Full-scale experimental tests were conducted on 24 typical precast concrete box culverts designed as per ASTM C1433. Six full-scale $2.4 \mathrm{~m}$ span concrete box culverts were tested to failure by subjecting each culvert to the AASHTO HS20 wheel load. Each structure was loaded incrementally up to failure in which crack initiation and propagation were identified and recorded at each step. It was shown that all the test structures behaved in flexural mode up to and beyond the standard loads. Therefore, the test results indicated that flexure governed the behavior required by AASHTO Specifications. Three-dimensional nonlinear finite element models of the test structures were developed and compared with the experimental results. It was shown that the actual shear capacity exceeded the factored critical shear force for all the ASTM C1433 box culverts. The study concluded that shear is not the governing behavior mode for the concrete box culverts, and it was recommended that the live load distribution width equations along with the provisions for shear transfer devices for box culverts required in the AASHTO Standard must be revised. The study also concluded that there is no need for shear transfer device across the joints of adjacent precast concrete box culverts.

Awwad et al. (2008) reported the results of a study comparing the 3D-FEA versus 2D plane frame results of a new four-sided box culvert with span length of $5.4 \mathrm{~m}(18 \mathrm{ft})$ and a rise of $2.4 \mathrm{~m}(8 \mathrm{ft})$. The culvert was subjected to various combinations of earth loading from the soil cover, lateral earth pressure, and AASHTO HS20 wheel loading applied at center or edge along mid-span of the top slab. As the soil cover increases from 0 to $3 \mathrm{~m}(10 \mathrm{ft})$, wheel loads were projected to the top slab using ASTM C890 procedure. The results showed that the effect of wheel loading along mid-span is significant and that the edge loading condition for 
a single box is more critical than center loading for soil cover less than $0.9 \mathrm{~m}(3 \mathrm{ft})$. The earth fill loading tends to gradually dominate as the soil cover increases. It was shown that moments from plane frame analysis and 3D FEA gave similar results.

Orton et al. (2015) reported experimental data from field testing of multi-cell reinforced concrete box culverts under soil fill. This study was performed to quantify the reduction of live-load effects with increasing fill depth since the current structural analysis procedures are overly conservative in predicting the live-load effects. The study investigated experimentally the effects of truck loads on reinforced concrete box culverts classified as bridges (where spans are greater than $6 \mathrm{~m}(20 \mathrm{ft}))$ under soil fills of different thickness. The study considered ten existing reinforced concrete box culverts with fill depths ranging from $0.76 \mathrm{~m}(2.5$ $\mathrm{ft})$ to $4.1 \mathrm{~m}(13.5 \mathrm{ft})$. Test results showed that the live-load effect does diminish with increasing fill depth. It was shown that at depths beyond $1.82 \mathrm{~m}(6 \mathrm{ft})$, the live-load pressures are less than $10 \%$ of the dead-load pressure, and this fill depth was considered as a point at which live-load effects may be neglected. This conclusion matches the results reported earlier by Awwad et al. (2008). Furthermore, the AASHTO LRFD Bridge Design Specifications (2012) were found to be overly conservative in predicting strains and displacements compared with field data for fill depths less than $2.4 \mathrm{~m}(8 \mathrm{ft})$. The primary source of conservatism is likely the two-way action in the top slab of the culvert.

Acharya et al. (2016) reported the results of a parametric study by investigating the influence of concrete pavement thickness, fill depth, wheel loads, and culvert span on the load distributions. The study was based on the results of a comprehensive field study of a single-cell low-fill box culvert. The culverts were instrumented with displacement transducers and pressure cells to capture deformations and pressures resulting from different combinations of wheel loads. It was shown that the intensity of the vertical pressure gradually decreased with an increase in the concrete pavement thickness and fill depth because the wheel load was distributed over a wider area. The vertical pressure on top of the culvert decreased with the increase of the culvert span. The study demonstrated that the AASHTO pressure distribution methods are overly conservative for the wheel load distribution on a low-fill box culvert under rigid pavement. The difference in the calculated vertical pressure decreased with the increase of the fill depth. For all the fill depths considered, the calculated pressure by the AASHTO LRFD code was higher than that by the AASHTO Standard Specifications. At the higher fill depth $(2.4 \mathrm{~m})$ and wider span, the calculated pressure by the AASHTO Standard Specification closely matched the pressure found by the numerical method.

\section{Description of Box Culverts}

\section{Geometry}

A typical three-dimensional precast concrete box culvert is shown in Figure 1. The main geometric parameters of a box culvert are the span length, rise, laying 
width, haunches, wall thickness and top/bottom slab thicknesses. A box culvert with span length $(\mathrm{S})$ of $7.2 \mathrm{~m}(24 \mathrm{ft})$ is investigated in this study. The culvert had constant rise of $2.4 \mathrm{~m}(8 \mathrm{ft})$, constant slab and wall thicknesses of $0.3 \mathrm{~m}(1 \mathrm{ft})$, and haunches at each corner of $0.3 \mathrm{~m} \times 0.3 \mathrm{~m}(1 \mathrm{ft} \times 1 \mathrm{ft})$. The laying width of the section was chosen as the standard $1.8 \mathrm{~m}(6 \mathrm{ft})$. The box section selected for this study was labeled as B24, which correspond to the span length. The overall weight and possible transporting the box culvert to a construction site was not addressed in this investigation.

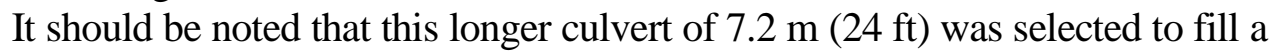
need to provide practical structural analysis of concrete box culverts spanning more than $3.6 \mathrm{~m}(12 \mathrm{ft})$ and less than $9 \mathrm{~m}(30 \mathrm{ft})$. The ASTM Standard covers precast culverts with spans up to $3.6 \mathrm{~m}(12 \mathrm{ft})$, and this research will allow engineers to address box culverts reaching up to $7.2 \mathrm{~m}$ ( $24 \mathrm{ft})$.

\section{Figure 1. Typical 3D Precast Concrete Box Culvert}

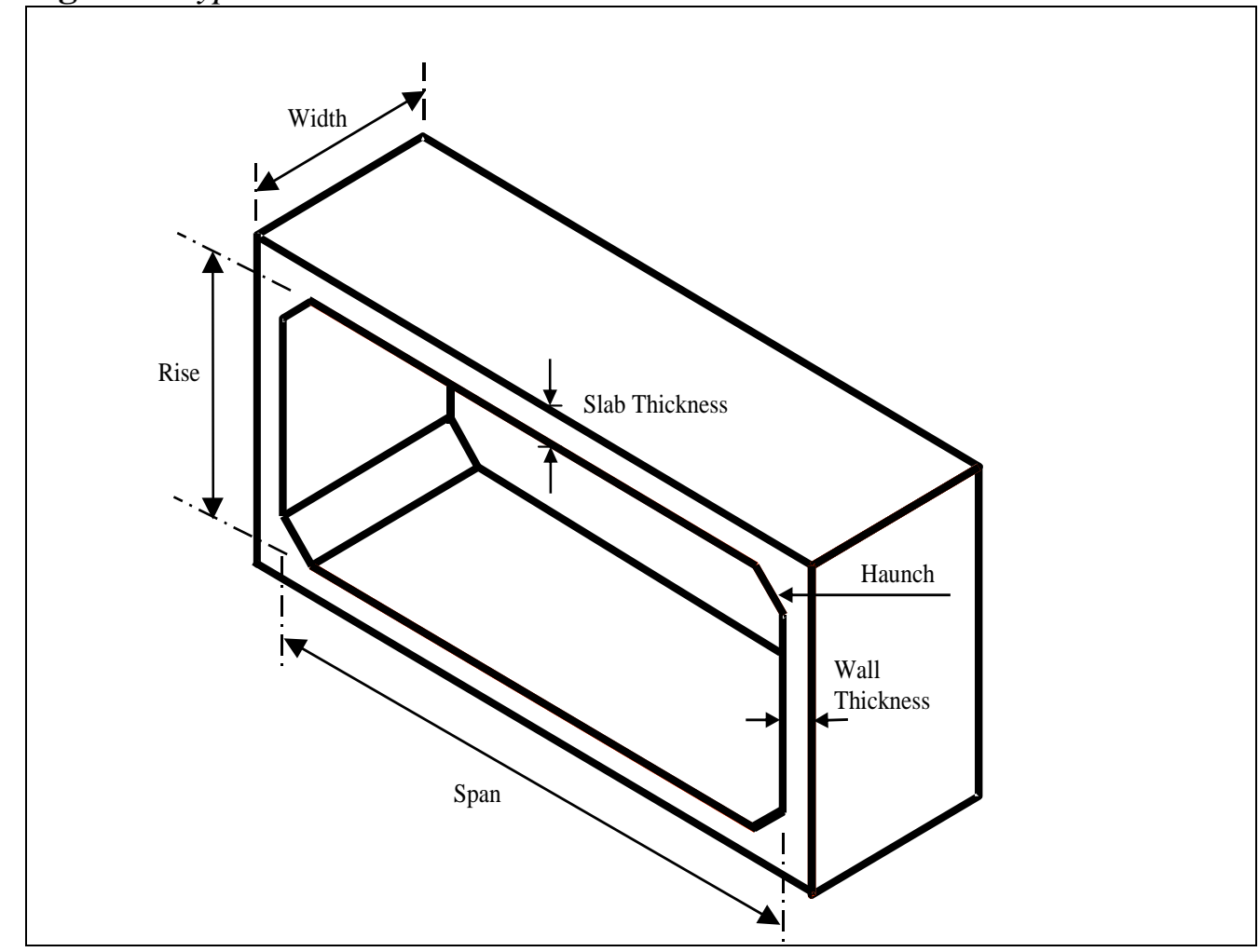

\section{Material Properties}

The material properties used in modeling the precast concrete box culvert was assumed to be normal-strength concrete with compressive strength of $27.6 \mathrm{MPa}$ $(4,000 \mathrm{psi})$, modulus of elasticity $24.8 \mathrm{GPa}\left(3.6 \times 10^{6} \mathrm{psi}\right)$, and Poisson's ratio 0.2. A typical $19 \mathrm{kN} / \mathrm{m}^{3}\left(120 \mathrm{lbs} / \mathrm{ft}^{3}\right)$ unit weight " $\gamma$ " of soil was used and a friction angle $\phi$ was assumed to be $30^{\circ}$ for well-drained granular fill material. The soil is considered at rest condition with a lateral pressure coefficient $k_{0}$ of 0.5 (where $k_{0}=$ $1-\sin \phi)$. To be conservative, it was assumed that the depth of water table to be 
below the culvert and there was no stream running water.

Loading

Figure 2 shows the various critical applied loads that will influence the load distribution in precast concrete box culverts. The culverts were subjected to overburden pressure due to soil cover, lateral earth pressures, and the standard AASHTO HS20 truck wheel load. The culvert self-weight was included in the comparative analysis of 3D-FEA vs 2D frame analysis. However, the culvert selfweight should be part of the load combination of the soil and live loadings in the final analysis and design of the culverts. The height of soil cover $(Z)$ above the top slab was varied from $0 \mathrm{~m}$ (no cover) to $3 \mathrm{~m}(10 \mathrm{ft})$, with increments of $0.6 \mathrm{~m} \mathrm{(2 \textrm {ft } )}$ and the resulting overburden pressure $(\gamma Z)$ was applied uniformly to the top slab. The lateral earth effect was modeled as linearly varying trapezoidal pressures on the culverts walls, starting with $\left(k_{0} \gamma Z\right)$ at the top slab level. The soil bearing pressure below the bottom slab was modeled by means of linear springs of 268 $\mathrm{kN} / \mathrm{m}^{2} / \mathrm{m}\left(50 \mathrm{lbs} / \mathrm{in}^{2} / \mathrm{in}\right)$.

Figure 2. Typical Earth and HS2O Wheel Loading on the Culvert

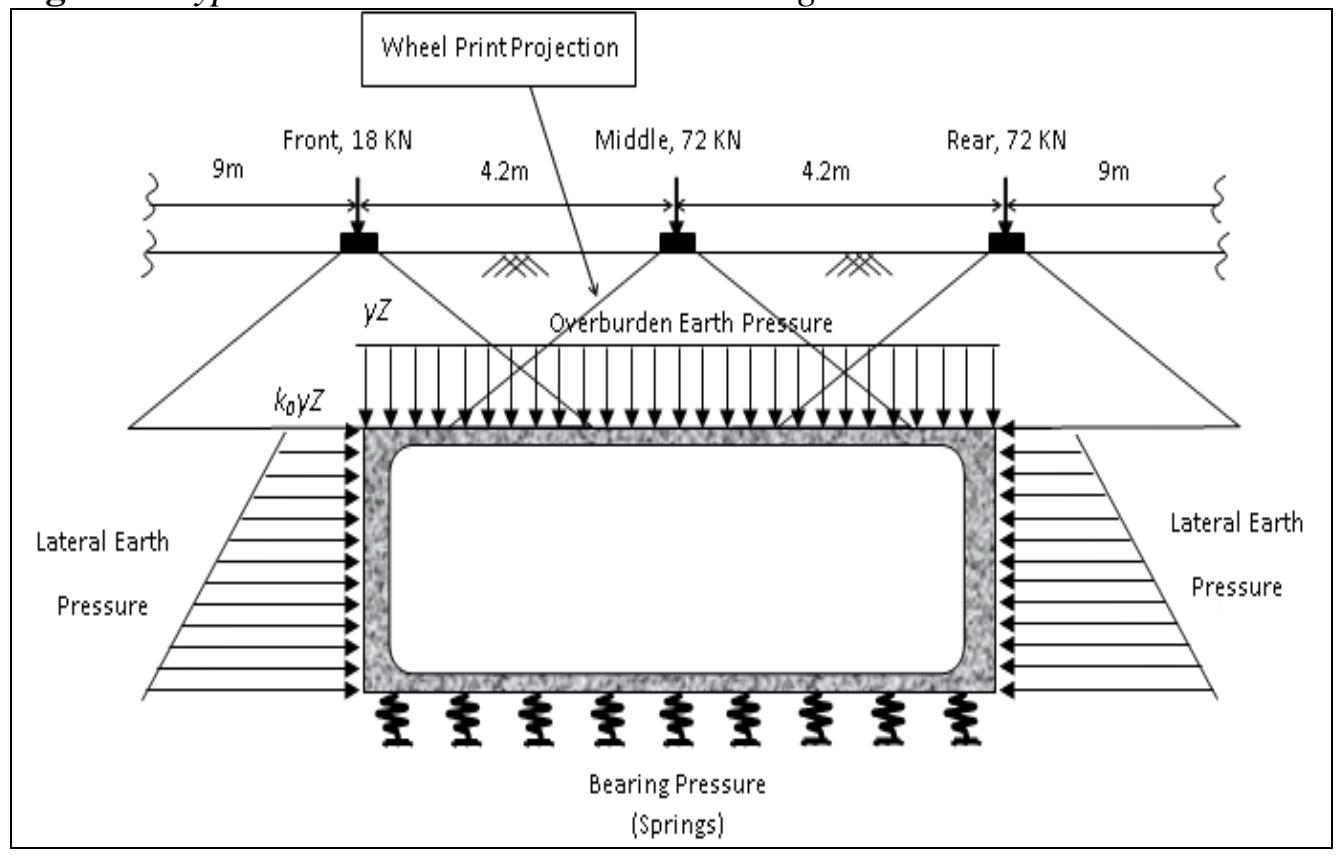

In the 3D-FEA, AASHTO HS20 truck consists of 2 lines of wheels spaced $1.8 \mathrm{~m}$ (6 ft) apart. Each line has 18, 72, and $72 \mathrm{kN}$ (4, 16, and $16 \mathrm{kips})$ concentrated wheel loads as shown in Figure 2. AASHTO and ASTM C1433 (2016) specify that a wheel load is to be applied as a tire print over an area of 0.50 $\mathrm{m} \times 0.25 \mathrm{~m}$ (20 in $\times 10$ in) directly to the top slab of a culvert for soil cover less

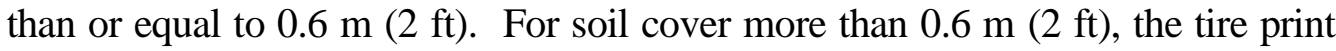
area is projected using ASTM C890 (2013) equation $(W+1.75 Z) \times(L+1.75 Z)$, where $W$ is the width (20 in) and $L$ is the length (10 in) of the tire print. Two wheel loading positions along mid-span are considered: (i) Centered Loading where the projection of the tire print of the middle wheel is placed in the center of top slab 
along mid-span and (ii) Edge Loading where the projection of the tire print of the wheel is placed at the edge of top slab along mid-span. These two loading conditions were considered based on a study by Awwad et al. (2008) in which several wheel load positions were investigated, located from edge to center along mid-span. The maximum values of bending moments and deflections in the top slab, as expected, decreased as the tire print was moved from edge toward the center. The centered and edge wheel loadings along mid-span were therefore selected to represent extreme loading conditions encompassing all other possible intermediate wheel load positions. The AASHTO Standard Bridge Specifications (2002) consider an impact factor for the dynamic live load effect as follows: $30 \%$

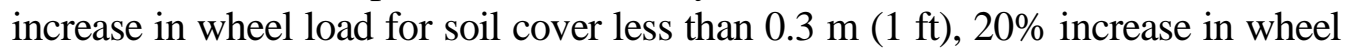
loads for soil cover between 0.3 and $0.6 \mathrm{~m}$ ( 1 and $2 \mathrm{ft}), 10 \%$ increase in wheel loads for soil cover between 0.6 and $0.9 \mathrm{~m}$ ( 2 and $3 \mathrm{ft}$ ), and no impact for soil covers more than $1.2 \mathrm{~m}(4 \mathrm{ft})$.

\section{Load Combinations}

The concrete box culvert selected for this study was analyzed, subject to the variable soil pressure and static wheel loading described earlier. The culvert was subjected to both Centered and Edge wheel loadings. In addition, soil loading was applied in three stages as follows: Case 1 considers only the overburden pressure on the top slab for the various soil covers selected and assumes the culverts to be simply supported by hinges under the side walls. Case 2 is similar to Case 1 but with the addition of lateral earth pressure applied to the side walls. Case 3 considers all soil pressures on the culvert slabs and walls, in addition to bearing springs under the bottom slab which support the culverts. The concrete culvert was analyzed considering the various load combinations of six soil covers, two wheel positions, and three earth loading cases.

\section{Finite Element Modeling}

The concrete box culverts were modeled using the finite element analysis computer program SAP2000. ${ }^{2}$ A mesh sensitivity analysis was conducted and a suitable discretization using $0.15 \mathrm{~m} \times 0.15 \mathrm{~m}(0.5 \mathrm{ft} \times 0.5 \mathrm{ft})$ four-node shell elements with six degrees of freedom at each node was adopted. The concrete slabs and walls were modeled as linear elastic four-node shell elements that account for plate bending in the slab, and bending with axial behavior in the side walls. The shell thickness of $0.3 \mathrm{~m}$ (12 in) was used for the slabs and walls while haunches are modeled using an equivalent thickness of $0.38 \mathrm{~m}$ (15 in).

The concrete box culverts were also analyzed as 2D plane frames per ASTM and AASHTO procedures. A unit-width is considered in the analysis and the corresponding earth pressures are applied in the three stages discussed earlier. For

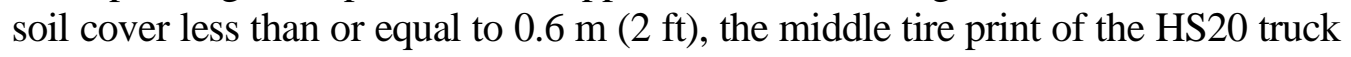

${ }^{2}$ SAP2000 (Version 17) Berkeley, California: Computers and Structures Inc. 
is applied at mid-span of the top frame member and is divided by the distribution width suggested by AASHTO Standard Bridge Specifications (2002), $E$ (ft) $=4+$ $0.06 S_{\text {eff, where }} S_{\text {eff }}(\mathrm{ft})$ is the effective span length, measured between midhaunches ( $S_{\text {eff }}=$ clear span $S$ - haunch width). When the soil cover exceeds $0.6 \mathrm{~m}$ $(2 \mathrm{ft})$, the tire prints are projected using procedures specified in ASTM C890. Noting that the centered and edge wheel loading condition become identical in the $2 \mathrm{D}$ analysis.

The finite element model of a typical culvert B24 subjected to edge wheel loading, overburden and lateral earth pressures with $Z=0.6 \mathrm{~m}(2 \mathrm{ft})$, supported by bearing springs distributed below the bottom slab, as described in Case 3 . The corresponding deflected box culvert and longitudinal bending moment distribution in the slabs and walls are shown in Figure 3. The longitudinal moment is the bending moment about the transverse axis which is used in determining the main reinforcing steel in the culvert.

Figure 3. Deflection and Bending Moment in Culvert B24 under Edge Loading (Case 3, $Z=0.6 \mathrm{~m}$ )

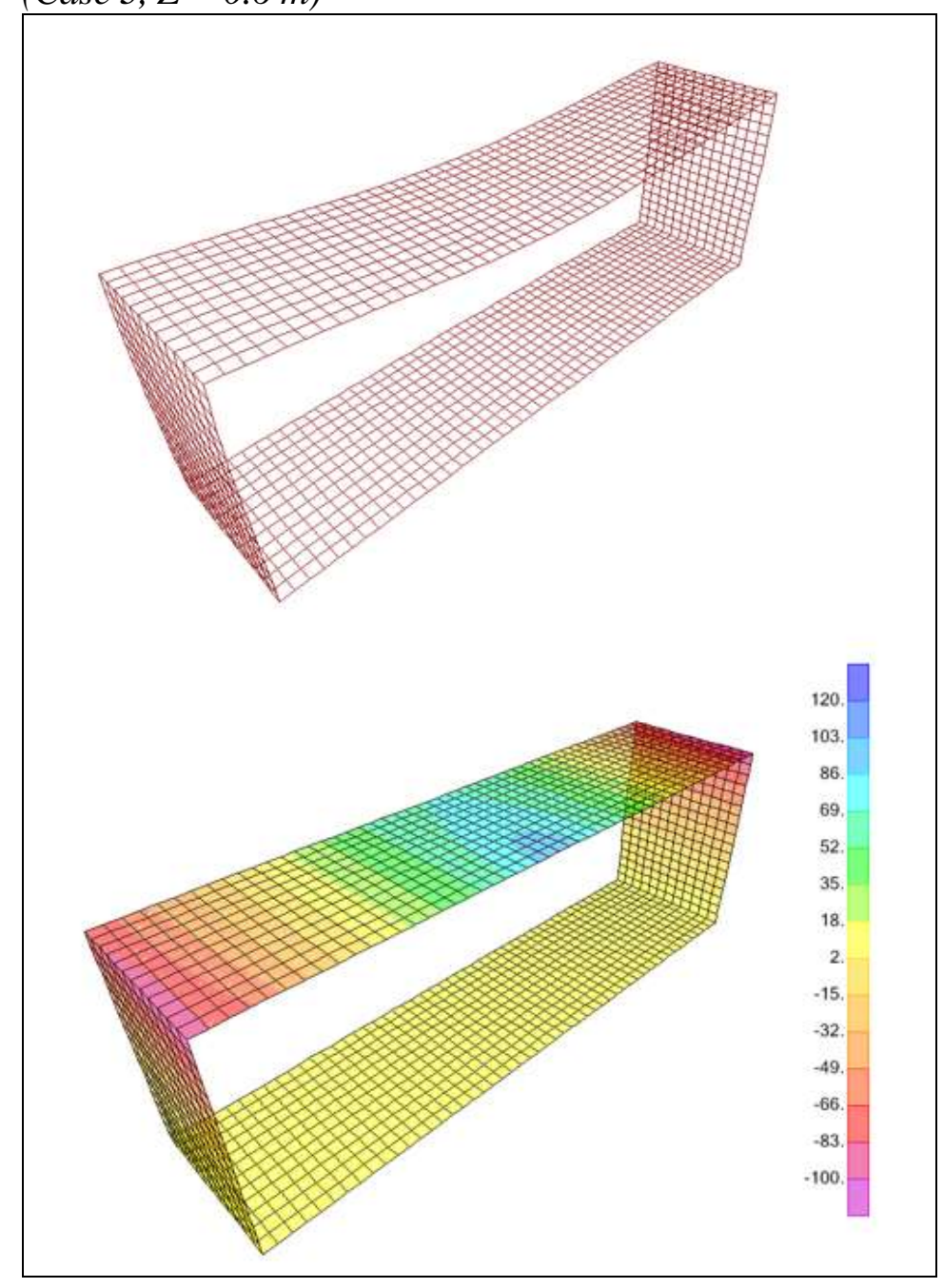




\section{Results}

The critical bending moments $\left(M_{p}\right.$ and $\left.M_{n}\right)$ were identified at mid-span and the wall support of the top slab along with the maximum vertical deflection $(D)$ at mid-span for all culverts and load cases considered in this investigation. The maximum positive bending moments, negative bending moments, and deflections for all three culverts (B12, B18, and B24) investigated by Awwad (2008) are summarized in Table 1. Typical FEA results for the culvert with span length of 7.2 $\mathrm{m}(24 \mathrm{ft}$ or B24) for Case 1 are shown in Figure 4. The 3D FEA and 2D Frame analysis results are plotted along the culverts laying width $(1.8 \mathrm{~m}$ or $6 \mathrm{ft})$ for selected soil covers $(\mathrm{Z}=0.6 \mathrm{~m}(2 \mathrm{ft})$ and $1.8 \mathrm{~m}(6 \mathrm{ft}))$ for individual edge and centered tire loading, earth loading, and total combined tire and earth loading.

General observations can be made to all three culverts (B12, B18, and B24) results that were summarized in Table 1 . The edge condition results are higher than the centered ones for soil covers " $Z$ " less than $0.6 \mathrm{~m}(2 \mathrm{ft})$. The difference between edge and centered conditions decreases when the soil cover exceeds 1.2 $\mathrm{m}(4 \mathrm{ft})$, and becomes insignificant for soil cover greater than $3 \mathrm{~m}(10 \mathrm{ft})$. This is consistent with geotechnical engineering practice, the deeper soil cover tends to lessen the influence of the wheel load position and its concentration by spreading it more evenly to the top slab. The effect of overburden pressure only (Case 1), overburden and lateral earth pressure (Case 2), and overburden, lateral, and bearing pressure (Case 3) on the box culvert were analyzed and compared with reference Case 1. The lateral pressure added in Case 2 tends to camber the top slab upwards, resulting in a decrease in the positive moments and deflections and an increase in the negative moments in the top slab. Applying bearing pressure to the bottom slab in Case 3 has the reverse counter effect. The results in Table 1 showed that the difference between the three load cases is more significant for the shortspan culvert B12, and is less significant for the long-span culverts B18 and B24, namely between Case 1 and Case 2 . This is due to the fact that the lateral pressure effect in Case 2 is similar for all three spans considered since the culvert rise is kept constant; the lateral effect will therefore be more significant for the short-span culverts with relatively smaller values of moments and deflections in the top slab.

The FEA results for culvert B12 showed a decrease of approximately $13 \%$ in the maximum positive moment in the top slab for the load case with lateral pressure (Case 2 versus Case 1); this decrease is reduced to about $4 \%$ when bearing pressure was added (Case 3 versus Case 1). Correspondingly, an increase in the maximum negative moments of about $15 \%$ and $4 \%$ is observed when considering Cases 2 and 3 versus Case 1, respectively. The maximum deflection in the top slab is also decreased by about $20 \%$ for Case 2, compared to Case 1 . The deflection resulted from load Case 3 is excluded from the comparison since it includes the settlement due to presence of bearing springs. 
Table 1. Box Culverts B12, B18, and B24: Maximum Positive Moments, Negative Moments, and Deflections for All Cases and Conditions Considered \begin{tabular}{|l|c|c|c|c|c|c|c|c|c|}
\hline Culvert B12 & $\mathrm{Z}=0 \mathrm{~m}$ & $\mathrm{Z}=0.6 \mathrm{~m}$ & $\mathrm{Z}=1.2 \mathrm{~m}$ & $\mathrm{Z}=1.8 \mathrm{~m}$ & $\mathrm{Z}=2.4 \mathrm{~m}$ & $\mathrm{Z}=3.0 \mathrm{~m}$ \\
\cline { 2 - 13 } \\
\hline
\end{tabular}

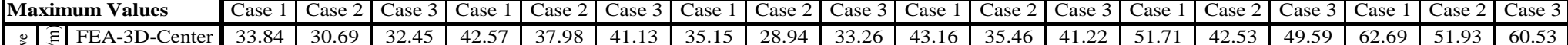

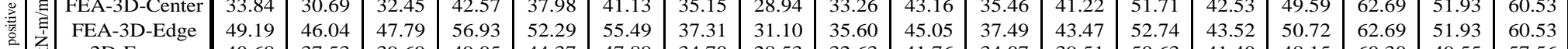
\begin{tabular}{|l|l|l|l|l|l|l|l|l|l|l|l|l|l|l|l|l|l|l|l|} 
2D-Frame & 40.68 & 37.53 & 39.69 & 49.05 & 44.37 & 47.88 & 34.70 & 28.53 & 32.63 & 41.76 & 34.07 & 39.51 & 50.63 & 41.40 & 48.15 & 60.30 & 49.55 & 57.56 \\
\hline
\end{tabular} \begin{tabular}{|c|c|c|c|c|c|c|c|c|c|c|c|c|c|c|c|c|c|c|}
\hline FEA-3D-Center & 19.76 & 22.82 & 21.11 & 29.84 & 34.43 & 31.28 & 34.20 & 40.28 & 36.00 & 43.20 & 50.76 & 45.09 & 51.98 & 61.02 & 54.00 & 63.00 & 73.49 & 65.03 \\
FEA-3D-Edge & 29.07 & 32.22 & 29.97 & 37.94 & 42.66 & 39.02 & 36.18 & 42.26 & 37.80 & 45.23 & 52.79 & 46.85 & 53.01 & 62.01 & 54.86 & 63.00 & 73.49 & 65.03 \\
\hline
\end{tabular}

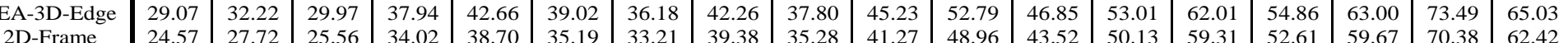

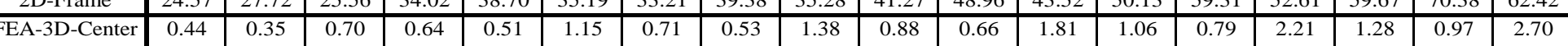

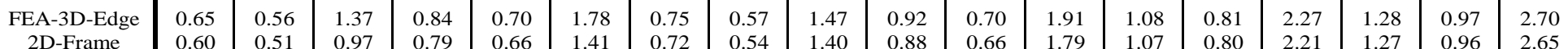

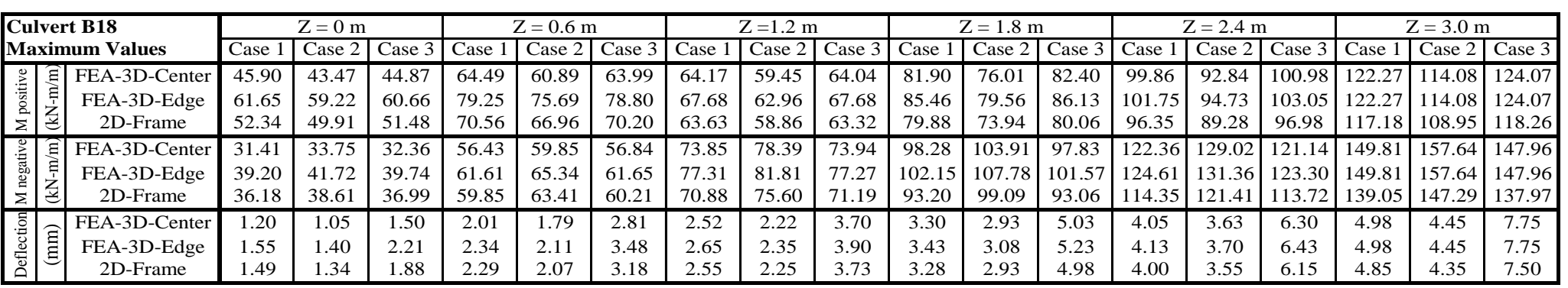

\begin{tabular}{|c|c|c|c|c|c|c|c|c|c|c|c|c|c|c|c|c|c|c|c|}
\hline \multirow{2}{*}{\multicolumn{2}{|c|}{\begin{tabular}{|l|} 
Culvert B24 \\
Maximum Values \\
\end{tabular}}} & & \multicolumn{3}{|c|}{$Z=0.6 \mathrm{~m}$} & \multicolumn{3}{|c|}{$\mathrm{Z}=1.2 \mathrm{~m}$} & \multicolumn{3}{|c|}{$\mathrm{Z}=1.8 \mathrm{~m}$} & \multicolumn{3}{|c|}{$\mathrm{Z}=2.4 \mathrm{~m}$} & \multicolumn{3}{|c|}{$\mathrm{Z}=3.0 \mathrm{~m}$} \\
\hline & & \multicolumn{2}{|c|}{\begin{tabular}{l|l} 
& $2=0 \mathrm{~m}$ \\
Case 1 & Case \\
\end{tabular}} & \multirow{2}{*}{\begin{tabular}{|c|} 
Case 3 \\
5670
\end{tabular}} & \multirow{2}{*}{$\frac{\text { Case 1 }}{89.55}$} & \multirow{2}{*}{$\frac{\text { Case } 2}{86.63}$} & \multirow{2}{*}{$\frac{\text { Case 3 }}{89.15}$} & \multirow{2}{*}{$\frac{\text { Case } 1}{100.26}$} & \multirow{2}{*}{\begin{tabular}{|l|} 
Case 2 \\
96.44
\end{tabular}} & \multirow{2}{*}{$\frac{\text { Case } 3}{100.62}$} & \multirow{2}{*}{$\frac{\text { Case } 1}{131.49}$} & \multirow{2}{*}{$\frac{\text { Case 2 }}{126.77}$} & \multirow{2}{*}{$\frac{\text { Case 3 }}{132.48}$} & \multirow{2}{*}{\begin{tabular}{|l} 
Case 1 \\
161.37 \\
\end{tabular}} & \multirow{2}{*}{$\frac{\text { Case 2 }}{155.66}$} & Case 3 & \multirow{2}{*}{$\frac{\text { Case 1 }}{197.24}$} & \multirow{2}{*}{$\frac{\text { Case 2 }}{190.62}$} & \multirow{2}{*}{\begin{tabular}{|l|} 
Case 3 \\
199.44 \\
\end{tabular}} \\
\hline & FEA & 57.78 & 55.85 & & & & & & & & & & & & & 162.90 & & & \\
\hline & & & & 72. & 4.49 & & & 5.21 & & & & & & & & & & & \\
\hline & & 33 & 60.35 & 61.38 & 93.92 & 90. & 93.51 & 9.68 & 95.85 & 99.90 & 12 & 12 & $12 \mathrm{c}$ & 46 & 70 & 63 & 43 & 77 & 193 \\
\hline \multirow{3}{*}{ 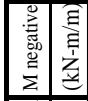 } & FEA & 56 & & 4 & 9 & & \begin{tabular}{|ll}
9 \\
\end{tabular} & 29.11 & & 12 & & & & & & & 0 & 2 & 4 \\
\hline & & .41 & & 50.00 & 94.23 & 97.0 & 91 & 134.33 & 137.88 & 1. & 2 & & 3 & 225.45 & 2 & 9 & 0 & 2 & 268.74 \\
\hline & & & & & 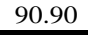 & & 91 & & & 12 & 95 & & & & & 15 & & 84 & \\
\hline & FEA- & 2.52 & & 2.82 & $\overline{4}$ & & 5 & & & & 8.7 & & 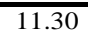 & & & $\overline{8}$ & 13.28 & 2.58 & $\overline{17}$ \\
\hline & & & & & & & & & & & & & & & & & & & \\
\hline & 2D-Fram & 90 & 2.68 & 3.2 & 5.15 & 4.85 & 6.25 & 6 & 6.13 & 8.35 & 8.70 & 8.20 & 1 & 10.75 & 10.15 & 13 & 13 & 12.38 & 3 \\
\hline
\end{tabular}


Figure 4. (a) Positive Moment (b) Negative Moment and (c) Deflections Results under Wheel Loading (Center and Edge) and Earth Pressure (Case 1, Z=0.6 m and $1.8 \mathrm{~m}$ ) for Culvert $\mathrm{B} 24$
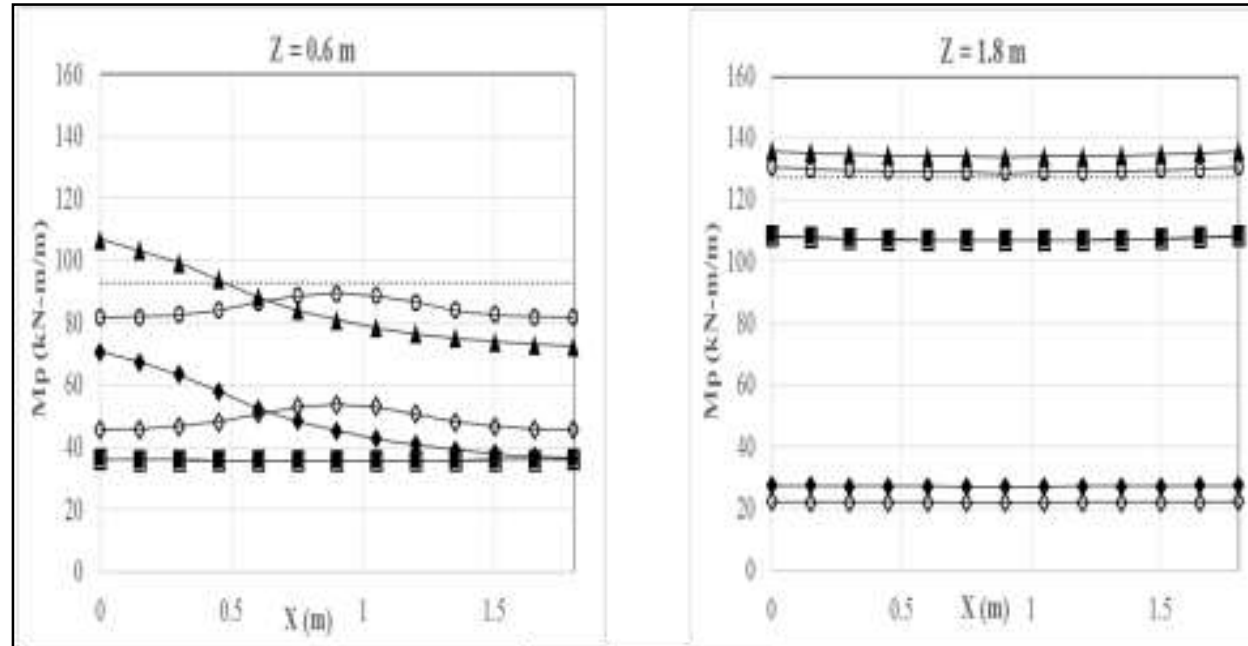

(a) Posithe Moment
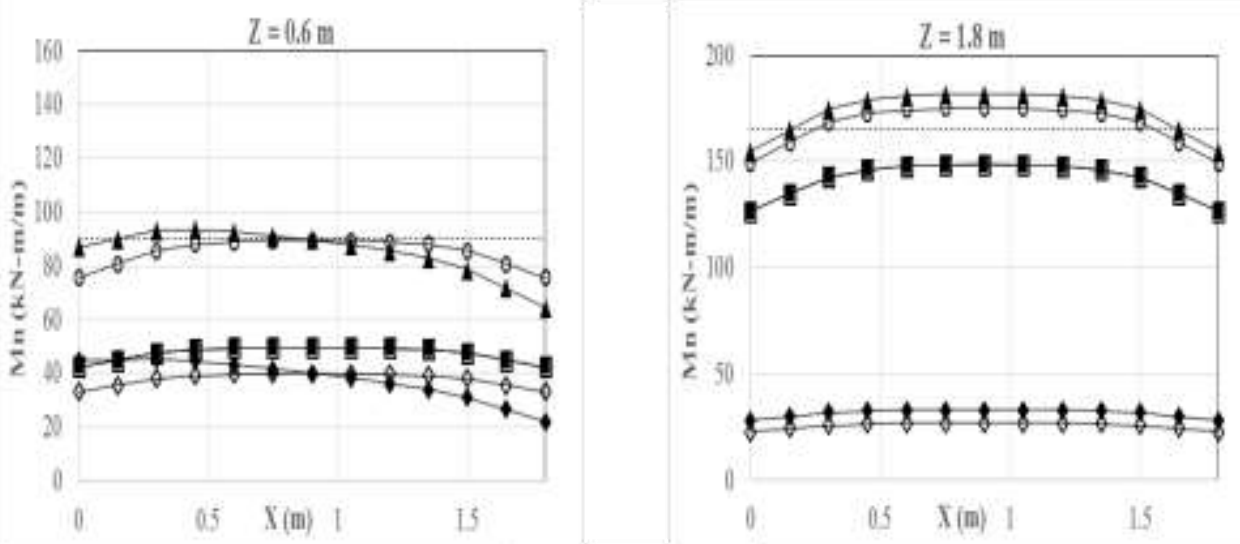

(b) Negative Noment
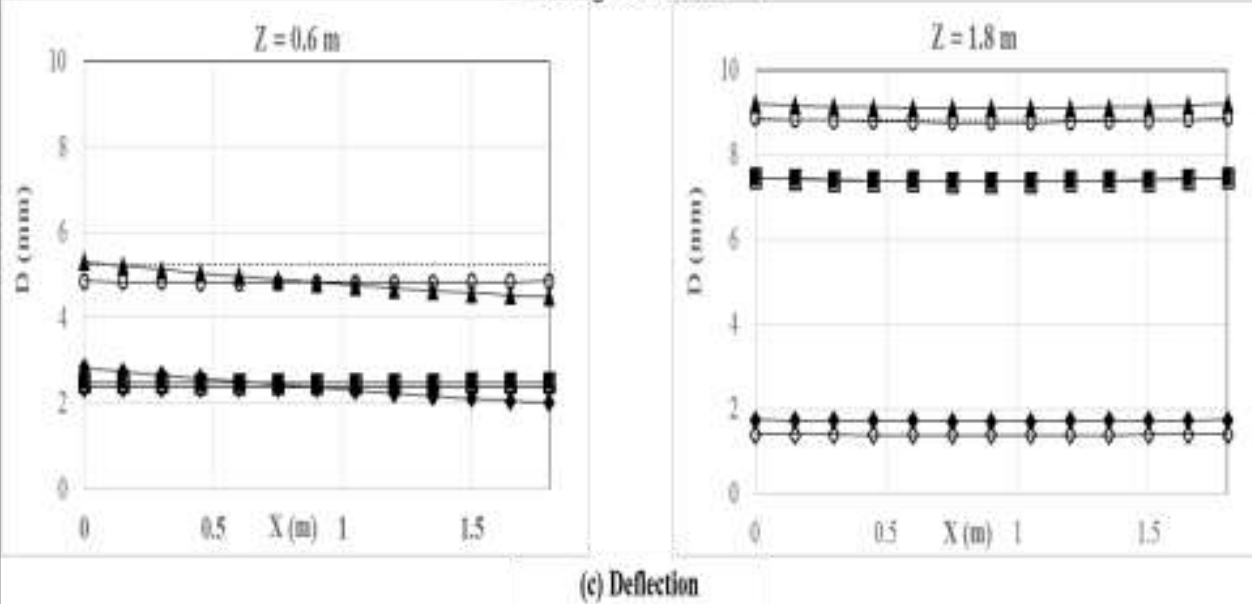

(c) Deflection
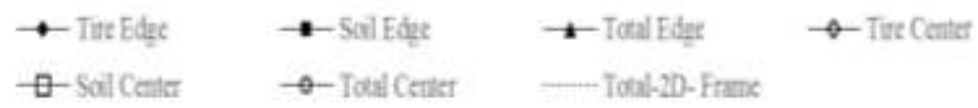
For the other two culverts B18 and B24, the finite element results indicated that an average of $5 \%$ increase is observed in the maximum positive or negative moments when lateral pressure is included (Case 2 versus Case 1) and almost no changes occur when bearing pressure is added (Case 3 versus Case 1). A decrease of $8 \%$ in the maximum deflection is observed for loading Case 2 versus Case 1. It was also noted that the percent increase or decrease in moments and deflections with respect to Case 1 are similar for 3D-FEA, center and edge, and 2D plane frame analyses.

The 3D-FEA results were compared with 2D plane frame analysis recommended by AASHTO Bridge Specifications and ASTM standards. The average bending moments and deflections were obtained for the three load Cases

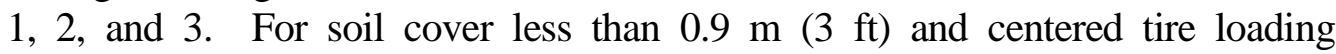
condition, 2D plane frame analysis overestimates the maximum positive and negative moments by $15 \%, 10 \%$, and $5 \%$ for culverts B12, B18, and B24 respectively; the maximum deflections were overestimated by $25 \%, 17 \%$, and $10 \%$, for Culverts B12, B18, and B24, respectively. For soil cover less than $0.9 \mathrm{~m}$ ( $3 \mathrm{ft}$ ) and edge wheel loading condition, the 2D frame analysis underestimates the maximum positive and negative moments by about $17 \%$, for Culvert B12, and by about $10 \%$ for Culverts B18 and B24. However, the maximum deflections was about $3 \%$ difference for all three culverts. For soil cover more than $0.9 \mathrm{~m}(3 \mathrm{ft})$, the results for centered and edge tire loading conditions were similar to the 3D-FEA and slightly greater than the 2D plane frame for all three culverts, reaching about $5 \%$ increase for edge loading.

\section{Conclusions}

This paper presented the results of a parametric study investigating the structural response of four-sided concrete box culverts using finite element analysis. Three culverts span lengths (B12, B18, and B24) were selected and analyzed under various load combinations of wheel load, earth pressure, and

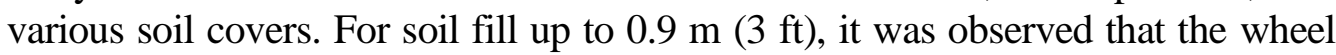
loading is dominant and it was found that the edge wheel loading was more critical than centered wheel loading at mid-span. As the soil cover increases above $0.9 \mathrm{~m}$ ( $3 \mathrm{ft}$ ), it was expected that the earth loading tends to gradually dominate, and for

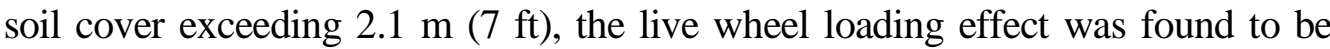
negligible when compared to dead load due to earth fill loading. Load cases with lateral earth pressure applied to side walls (Case 2) and bearing pressure applied to the bottom slab in addition to lateral pressure (Case 3), were compared with the case when only overburden pressure is applied to the top slab (Case 1). It was observed when comparing Case 2 loading combination relative to Case 1 loading: (a) the positive moments decreased by $13 \%$ for B12 and increased by $5 \%$ for B18 and B24; (b) the negative moments increased by $15 \%$ for B12 and increased by $5 \%$ for B18 and B24; and (c) the deflections decreased by $20 \%$ for B12 and decreased by $8 \%$ for B18 and B24. It was concluded that plane frame analysis leads to slightly conservative bending moment results when compared to 3D-FEA, 
it was off by $15 \%$ for short-span culverts (B12), $10 \%$ for B18, and $5 \%$ for longer span (B24) culverts.

\section{References}

AASHTO (2002) Standard Specifications for Highway Bridges, $17^{\text {th }}$ Edition. Washington, D.C.: American Association of State Highway and Transportation Officials (AASHTO).

AASHTO (2012) LRFD Bridge Design Specifications. $7^{\text {th }}$ Edition. Washington, D.C.: American Association of State Highway and Transportation Officials (AASHTO).

Abolmaali A, Garg A (2008) Shear Behavior and Mode of Failure for ASTM C1433 Precast Box Culverts. Journal of Bridge Engineering 13(4): 331-338.

Acharya R, Han J, Parsons R (2016) Numerical Analysis of Low-Fill Box Culvert under Rigid Pavement Subjected to Static Traffic Loading. International Journal of Geomechanics 16(5) 04016016.

ASTM - American Society for Testing and Materials (2013) Standard Practice for Minimum Structural Design Loading for Monolithic or Sectional Precast Concrete Water and Wastewater Structures. West Conshohocken, PA: C890-13, ASTM International.

ASTM - American Society for Testing and Materials (2016) Standard Specification for Precast Reinforced Concrete Monolithic Box Sections for Culverts, Storm Drains, and Sewers. West Conshohocken, PA: C1433-16, ASTM International.

ASTM - American Society for Testing and Materials (2016) Standard Specification for Precast Reinforced Concrete Monolithic Box Sections for Culverts, Storm Drains, and Sewers Designed according to AASHTO LRFD. West Conshohocken, PA: C1577-16, ASTM International.

Awwad E, Mabsout M, Sadek S, Tarhini K (2008) Parametric Study of Load Distribution in Four-Sided Concrete Box Culverts. Journal of Bridge Structures 4(2): 99-107.

Orton S, Loehr JE, Boeckmann A, Havens G (2015) Live-load Effect in Reinforced Concrete Box Culverts under Soil Fill. Journal of Bridge Engineering 20(11) 04015003. 
